\title{
研究論文 歯車の騒音・振動計測における平均成分の抽出法*
}

\author{
西田知照** 小林洋一** 塚 本尚 久***
}

Extraction of Average Component of Gear Vibrations and Gear Noises

Noriteru Nishida, Youichi Kobayashi and Naohisa Tsukamoto

\begin{abstract}
Vibrations and noises of gears consist of the average component and the fluctuant one. The former is the component which always appears in each tooth meshing. In general, this component consists of the meshing frequency and its harmonics. The latter is the component which fluctuates about the average component and is caused by the error of gears, torque fluctuation, and so on. In this report, the extraction of this average component by using a method of moving averages is described. This method is very effective for extracting the average component of gear noises or gear vibrations. The effectiveness of this method is shown theoretically and experimentally.
\end{abstract}

Key words : gear noise, gear vibration, average component, fluctuant component, moving average method, error of gear

\section{1. 緒言}

歯車け振動や騒音波形は平均成分と変動成分とに分 けら机る。前者は1歯のかみあいごとに繰り返し現机 る平均的な振動・騒音成分であり，後者は各歯での誤 差に上る動荷重の変動や計測時の雑音など平均成分の まわりにばらつく成分である。従って，動荷重や誤差 によって発生する成分であっても，どの歯に扔いても 規則正しく現机る成分は平均成分となる。従って，こ こでいう平均成分とは，一般的には，歯車の歯の 1 歯 1 歯のかみあいによって生じるかみあい周波数成分と その高調波を意味する。

歯車の振動と騒音の関係を調べようとする場合や, 歯車騒音の発生メカニズムを解明しようとする場合に は変動成分は除き，平均成分のみを抽出して検討する 上うにす机ば振動と騒音の関係などの把握が容易にな る.

平均成分の抽出法の一つとして加算平均法がある. しかし，この方法では 1 歯ごとの平均成分は抽出でき ない。また，加算平均を実行中に歯車の回転数が変化 したような場合には処理されたデータ中に回転変動に 上る誤差が入り込む危険さえある。

以下では, 平均成分の抽出法として, 移動平均法を

* 原稿受付 昭和 61 年 12 月 25 日. 昭和 61 年度精密工学会 九州支部福岡地方講演会 (昭和 61 年 11 月 21 日) にて発 表

** 正 会員 長崎大学丁学部（長崎市文教町 1-14)

*** 正会員 干葉工業大学 (習志野市津田沼 2-17-1)
考え，その効果について，理論抢よび実験的考察を行

う。具体的な振動・騷音波形の処理結果から，この移 動平均法は非常に有効な処理方法であることが分か 万.

平均成分の抽出が行えれば，変動成分すなわち雑音 成分の抽出は原波形から平均成分を除去することに よって容易に行うことができる。

\section{使用記号}

$f_{0}, \omega_{0}$ ：かみあい周波数 $(\mathrm{Hz})$ ，角周波数 $(\mathrm{rad} / \mathrm{s})$

$f_{m}, \omega_{m}$ : 回転周波数 $(\mathrm{Hz})$, 回転角周波数 $(\mathrm{rad} / \mathrm{s})$

$Z$ : 歯車歯数

$n$ : 歯車回転数 $(\mathrm{rpm})$

$T$ : 歯車 1 回転当たりの時間 ( $\mathrm{s}$ )

$\Delta t \quad: 1$ 歯当たりのかみあい時間 $(\mathrm{s})$

\section{2. 移動平均 法}

移動平均法は工学の分野ではもちろんのこと他分野 でも広く利用されている手法である。ここでは，理論 上歯車の歯のかみあいは 1 歯ごとに同じかみあいが繰 り返されるという性質を利用した移動平均法につい て，その効果を理論的に検討する。

歯車の速比が 1 対 1 の場合について考えると，歯の かみあいの状態は歯車の 1 回転ごとに誤差を含めて同 じ状態が繰り返されるものと考えることができる。す なわち，歯車の回転によって生じる振動・騒音波形の うち最も周期が長い成分でも，その周期は歯車の 1 回 
転相当の周期であり，他の成分はこれより短い周期を もつことになる．歯車の歯数を $Z$, 回転数を $n(\mathrm{rpm})$ とすると,歯車の回転周波数 $f_{m}$ 拈よびかみあい周波数 $f_{0}$ は次のように表さ机る。

$$
f_{m}=n / 60, \quad f_{0}=Z \cdot n / 60=Z \cdot f_{m}
$$

また，これらを回転角周波数で表現すると

$$
\omega_{m}=2 \pi f_{m}, \quad \omega_{0}=2 \pi f_{0}
$$

となる。式(1)の $f_{m}$ あるいは式 (2)の $\omega_{m}$ が最も周 期の長い成分であり，他の成分は，これらの高調波で あると考えることができる。

歯車の振動・騒音波形中のかみあい周波数成分や之 の高調波は, 歯車のもつ誤差や動荷重の変動, 負荷変 動などによって,その周波数や振幅が絶えず変化する. その結果, 周波数スペクトルとしては, かみあい周波 数 $f_{0}$ やその高調波 $i \cdot f_{0}(i=2,3, \cdots)$ のまわりに, $f_{m}$ 間 隔で多くの側帯波が現机る12).これらの側带波(ここ でいう変動成分であり，平均成分に対する雑音と考え る）を移動平均法によって消去する方法を以下に示 す。

$$
\left.\begin{array}{l}
\Delta t=\frac{1}{f_{0}}=\frac{2 \pi}{\omega_{0}} \\
T=\frac{1}{f_{m}}=\frac{2 \pi}{\omega_{m}} \\
\frac{T}{\Delta t}=\frac{\omega_{0}}{\omega_{m}}=\frac{f_{0}}{f_{m}}=Z
\end{array}\right\}
$$

と扔くとき， $\Delta t$ は1歯当たりのかみあい時間， $T$ は 歯車 1 回転当たりの時間を意味する。かみあい角周波 数が $\omega_{0}$ の波とその高調波（角周波数 $i \omega_{0}$ ) およびそ机 らの側带波（角周波数 $\left.i \omega_{0} \pm j \omega_{m}(i, j=1,2, \cdots)\right)$ を同 時に含んだ波が式 (4)で与えられるものとする.

$$
\begin{aligned}
V_{0}= & \sum_{i=1}^{\infty} a_{i} \cos \left(i \omega_{0} t+\alpha_{i}\right) \\
& +\sum_{i=1}^{\infty} \sum_{j=1}^{\infty} b_{i j} \cos \left\{\left(i \omega_{0} \pm j \omega_{m}\right) t+\beta_{i j}\right\}
\end{aligned}
$$

式 (4) の表亦波時間軸方向に $k \Delta t(k=1,2, \cdots, Z) た ゙$ けずらした波 $V_{k}$ を作る。この波は次式で表される。

$$
\begin{aligned}
V_{k}= & \sum_{i=1}^{\infty} a_{i} \cos \left\{i \omega_{0}(t+k \Delta t)+\alpha_{i}\right\} \\
& +\sum_{i=1}^{\infty} \sum_{j=1}^{\infty} b_{i j} \cos \left\{\left(i \omega_{0} \pm j \omega_{m}\right)(t+k \Delta t)+\beta_{i j}\right\} \\
= & \sum_{i=1}^{\infty} a_{i}\left[\cos \left\{i \omega_{0} t+\alpha_{i}\right) \cos i k \Delta t \omega_{0}\right. \\
& \left.-\sin \left(i \omega_{0} t+\alpha_{i}\right) \sin i k \Delta t \omega_{0}\right] \\
& +\sum_{i=1}^{\infty} \sum_{j=1}^{\infty} b_{i j}\left[\cos \left\{\left(i \omega_{0} \pm j \omega_{m}\right) t+\beta_{i j}\right\}\right. \\
& \times \cos \left\{\left(i \omega_{0} \pm j \omega_{m}\right) k \Delta t\right\}
\end{aligned}
$$

$$
\left.-\sin \left\{\left(i \omega_{0} \pm j \omega_{m}\right) t+\beta_{i j}\right\} \sin \left\{\left(i \omega_{0} \pm j \omega_{m}\right) k \Delta t\right\}\right]
$$$$
(k=1,2, \cdots, Z)
$$

ここで, 式 (3) から

$$
\Delta t \omega_{0}=2 \pi, \Delta t \omega_{m}=\Delta t \omega_{0} / Z=2 \pi / Z
$$

であることに注意すると，式 (5) はさらに次式の上う に変形される。

$$
\begin{aligned}
& V_{k}=\sum_{i=1}^{\infty} a_{i} \cos \left(i \omega_{0} t+\alpha_{i}\right) \\
&+\sum_{i=1}^{\infty} \sum_{j=1}^{\infty} b_{i j}\left[\cos \left\{\left(i \omega_{0} \pm j \omega_{m}\right) t+\beta_{i j}\right\} \cos \left( \pm j k \frac{2 \pi}{Z}\right)\right. \\
&\left.-\sin \left\{\left(i \omega_{0} \pm j \omega_{m}\right) t+\beta_{i j}\right\} \sin \left( \pm j k \frac{2 \pi}{Z}\right)\right] \\
&= \sum_{i=1}^{\infty} a_{i} \cos \left\{i \omega_{0} t+\alpha_{i}\right) \\
&+\sum_{i=1}^{\infty} \sum_{j=1}^{\infty} b_{i j}\left[\cos \left\{\left(i \omega_{0} \pm j \omega_{m}\right) t+\beta_{i j}\right\} \cos \left(j k \frac{2 \pi}{Z}\right)\right. \\
&\left.\mp \sin \left\{\left(i \omega_{0} \pm j \omega_{m}\right) t+\beta_{i j}\right\} \sin \left(j k \frac{2 \pi}{Z}\right)\right] \\
& \quad(k=1,2, \cdots, Z)
\end{aligned}
$$

式(7)を用いて，V=( $\left.V_{1}+V_{2}+\cdots+V_{Z}\right) / Z$ を作 万.

$$
\begin{aligned}
V= & \sum_{k=1}^{Z} V_{k} / Z \\
= & \sum_{i=1}^{\infty} a_{i} \cos \left(i \omega_{0} t+\alpha_{i}\right) \\
& +\frac{1}{Z} \sum_{i=1}^{\infty} \sum_{j=1}^{\infty} b_{i j}\left[\cos \left\{\left(i \omega_{0} \pm j \omega_{m}\right) t+\beta_{i j}\right\}\right. \\
& \times \sum_{k=1}^{Z} \cos \left(j k \frac{2 \pi}{Z}\right) \\
& \left.\mp \sin \left\{\left(i \omega_{0} \pm j \omega_{m}\right) t+\beta_{i j}\right\} \sum_{k=1}^{Z} \sin \left(j k \frac{2 \pi}{Z}\right)\right]
\end{aligned}
$$

ここで,

$$
\sum_{k=1}^{Z} \cos \left(j k \frac{2 \pi}{Z}\right)=0, \quad \sum_{k=1}^{Z} \sin \left(j k \frac{2 \pi}{Z}\right)=0
$$

であるので,

$$
V=\sum_{i=1}^{\infty} a_{i} \cos \left(i \omega_{0} t+\alpha_{i}\right)
$$

上なり平均成分，すなおち，かみあい周波数成分上之 の高調波のみ残り，変動成分（側带波）は除か机る。 いま，式（4）に示された成分以外の周期性を有しない 成分，例えば，白色雑音や単発的な信号などが原信号 に含まれている場合，これらの信号は完全には消去き れないが $1 / Z$ 倍されるので $\mathrm{SN}$ 比も向上寸る.

以上の処理は模式的には図 1 に示すように, 歯車 2 回転分の波を準備し，この波から歯車の 1 歯当たりの

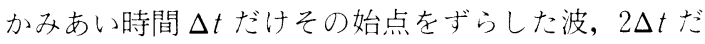




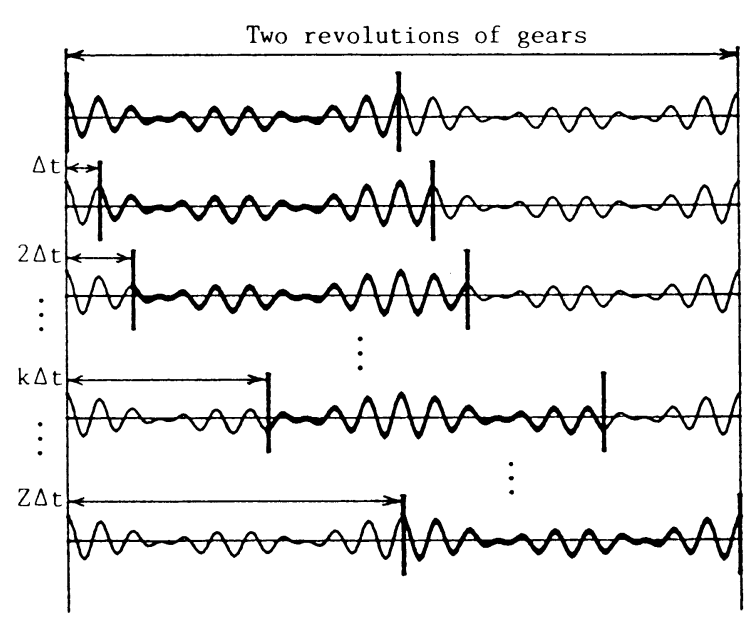

Fig. 1 Components in moving average

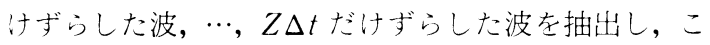
れら $Z$ 個の波を加え合わせることによって実現でき る。しかし，実際の処理に当たっては次のような注意 が必要である。まず，振動や騒音の原波形の収録中は 回転数を極力一定に保つことと, その期間の回転数ま たは 1 回転の周期を正確に検出する必要がある。なぜ ならばこの值によって $\Delta t$ の值を算出するからであ る。さらに, 時間軸方向のずらし量 $k \Delta t$ の值はデータ 収録時のサンプリング時間の精度と同じ精度になるよ うに四捨五入するのがよい。

以上の議論では歯車の速比を 1 対 1 としたが, 速比 が 1 対 1 でない場合でも，小歯車または大歯車を単独 で考えれば，その歯数抢よび回転数に関して，これま でに示した式はそのまま成立する。歯車の騒音や振動 中の変動成分は誤差の大きい歯車によって支配され る. 従って, 小歯車と大歯車のうち一方の誤差が他方 に比心゙て大きいことが分かれば，その誤差の大きい方 の歯車について以上の議論を適用すればよい. 変動成 分を支配しているのがどちらの歯車か明らかでない場 合には，移動平均の対象として準備すべき騒音または 振動波形の時間的長さは次に述べるように長くしなけ ればならない。

小歯車と大歯車の歯数比を最も簡単な整数比に直し た結果が $a$ 対 $b$ の場合は, 小歯車が $b$ 回転あるいは大 歯車が $a$ 回転す机ば両歯車の歯のかみあいは 1 周期 し, 完全に最初のかみあい位置に戻る。いいかえると, 両歯車についての総合誤差もこの周期で繰り返され る. 従って,この場合に準備す心゙き波形は小歯車の $2 b$ 回転分となる， $b$ 值が大きく $b=50$ の場合は 100 回 転分の波形が必要となる。このように多くの波形を準
Table 1 Specification of gears and running condition

\begin{tabular}{l|l|l}
\hline Number of teeth & $Z_{1}: Z_{2}$ & $40: 40$ \\
Module & $m$ & $5 \mathrm{~mm}$ \\
Face width & $b$ & $30 \mathrm{~mm}$ \\
Input RPM & $n$ & $600 \mathrm{rpm}$ \\
Output torque & $T_{o}$ & $9.8 \mathrm{Nm}$ \\
Meshing frequency & $f_{0}$ & $400 \mathrm{~Hz}$ \\
Rotational frequency & $f_{m}$ & $10 \mathrm{~Hz}$ \\
\hline
\end{tabular}

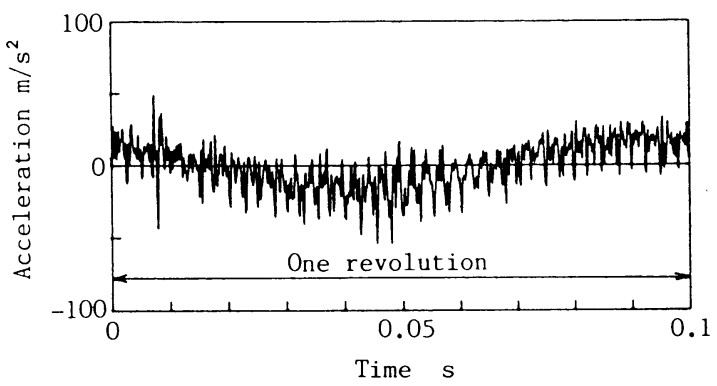

Fig. 2 Rotational vibration wave of a gear (before averaging)

備できない場合には，これよりずっと少ない回転数で 両歯車の歯のかみあいが完全には 1 周期しないまで も，ほぼ 1 周期する回転数を見い出せれば，これを 1 周期とみなして代用することもできる。この場合，移 動平均の効果は当然減るが, 移動平均処理をしない場 合と比べれば，一般には十分な処理効果が得られる。

速比が $a$ 対 $b$ の場合の歯数 $Z$ や回転数 $n$ の取扱い は次のようにすればよい. 速比が 1 対 1 の場合の歯車 の歯数と回転数をそれぞれ $Z, n$ とすれば，速比が $a$ 対 $b$ の場合はこれらの $Z, n$ をそれぞれ $b Z, n / b$ と置 き換えて扱う。

\section{3. 処 理 例}

\section{1 歯車の円周方向振動波形の処理}

以下の処理例において使用した歯車の諸元および運 転条件を表 1 に示す。

図 2 は歯車端面に取り付けた 1 個の加速度型ピック アップで検出した歯車の円周方向振動波形である。な お，実際には，後の高速フーリ工変換 (FFT) 処理に 必要なデー夕長, すなわち, 歯車 5 回転分のデー夕を 収録した。波形は歯車の 1 回転を 1 周期とする低周波 成分で波打っている。この低周波成分はピックアップ が重力の加速度を検出したものである。図 2 の波形に 対し FFT 処理を行った結果が図 3 である。歯車の回 転周波数 $(10 \mathrm{~Hz})$ 抢よびかみあい周波数 $(400 \mathrm{~Hz})$ と その高調波以外に多くの側帯波が生じている。ピック アップを 2 個用いることによってこの低周波成分（10 


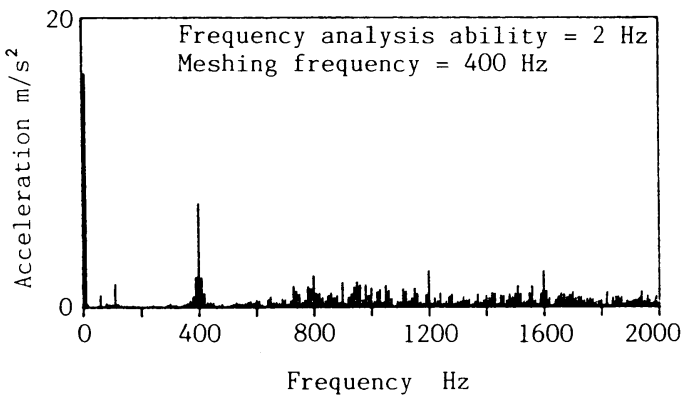

Fig. 3 Spectrum of rotational vibration of a gear (before averaging)

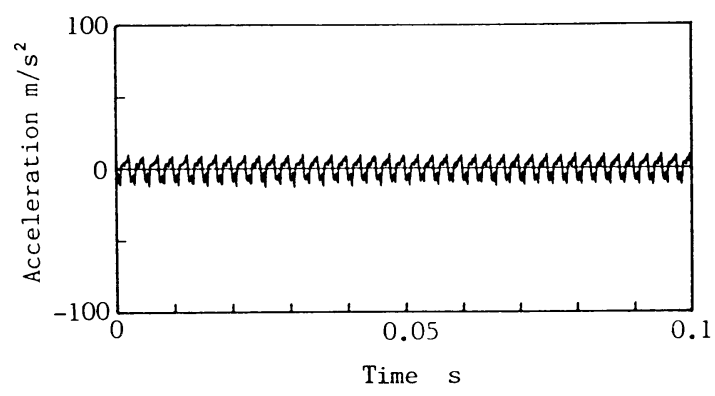

Fig. 4 Rotational vibration wave of a gear (after averaging)

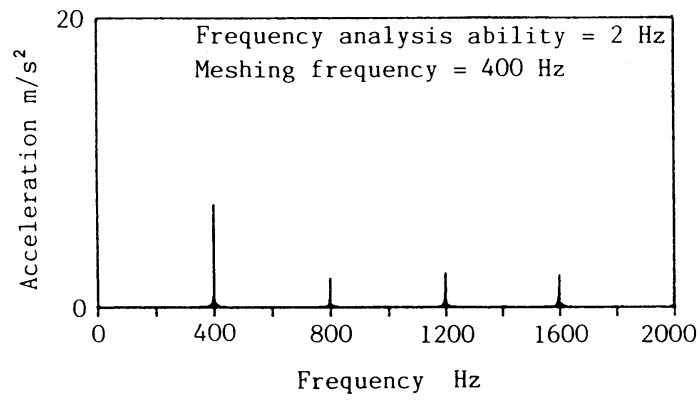

Fig. 5 Spectrum of rotational vibratoin of a gear (after averaging)

$\mathrm{Hz}$ )を相殺させることもできるが，側帯波はそのまま 残る。

これに対し，図 2 の波形に移動平均処理を行うと図 4 となる。図 4 によって, 低周波成分 $(10 \mathrm{~Hz})$ が除か れたばかりでなく，1歯ごとのかみあい振動波形がき れいに抽出されていることが分かる。図 4 の波形を FFT 処理すると図 5 が得られる. 図 5 から, 移動平均 法によって側帯波は完全に消え, かみあい周波数とそ の高調波だけが抽出されたことが分かる。

\section{2 歯車騒音波形の処理}

図 6 は歯車のかみあい点から軸方向に $100 \mathrm{~mm}$ の位 置に設定したマイクロホンで収録した騒音波形であ

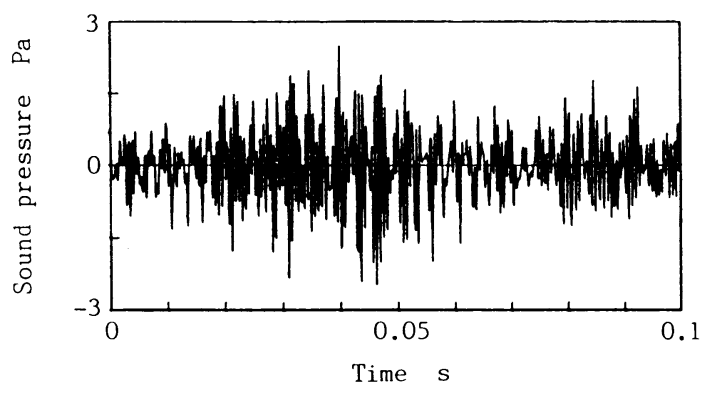

Fig. 6 Noise wave of gears (before averaging)

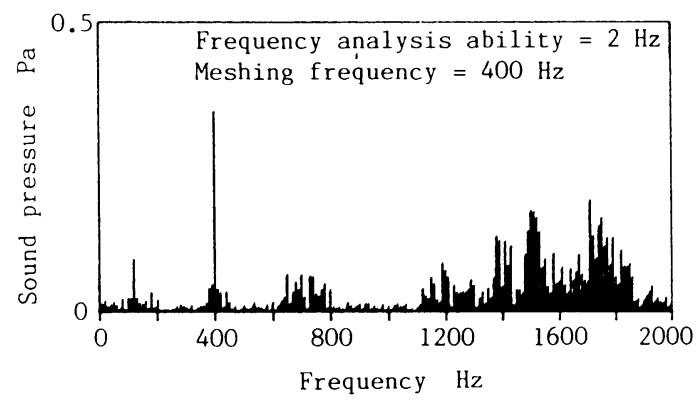

Fig. 7 Spectrum of gear noise (before averaging)

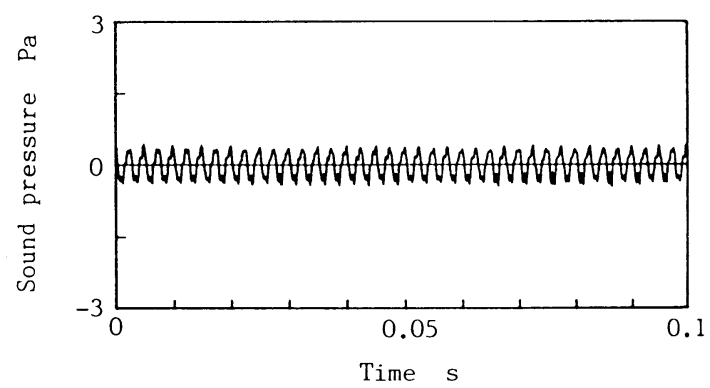

Fig. 8 Noise wave of gears (after averaging)

る. 前節の図 2 と同様に歯車 5 回転分のデータ中 1 回 転分のみを示している。騒音の振幅は歯車の 1 回転を 1 周期として変化している。これは歯車の偏心誤差に よって生じたものと考えられる11.また，1歯ごとのか みあい音波形は大きく乱れており，その形を認識する ことはむつかしい. 図6の波形を FFT 処理すると図 7 が得られる。図 7 には歯車の誤差によると思われる側 帯波 ${ }^{1) 2}$ を含め多くのスペクトルが現れている.図6の 波形に対し移動平均処理を施した結果が図 8 である. 移動平均法によって 1 歯ごとのかみあい音波形が明 りょうに抽出されていることが分かる。図 8 の波形を FFT 処理した結果が図 9 である.かみあい周波数 $(400$ $\mathrm{Hz}$ )とその高調波が残り，側帯波はほとんど消えてい る. $1400 \mathrm{~Hz}$ 付近と $1800 \mathrm{~Hz}$ 付近に少し残った成分 がある。これは，歯車の回転数が $600 \mathrm{rpm}$ からごくわ 


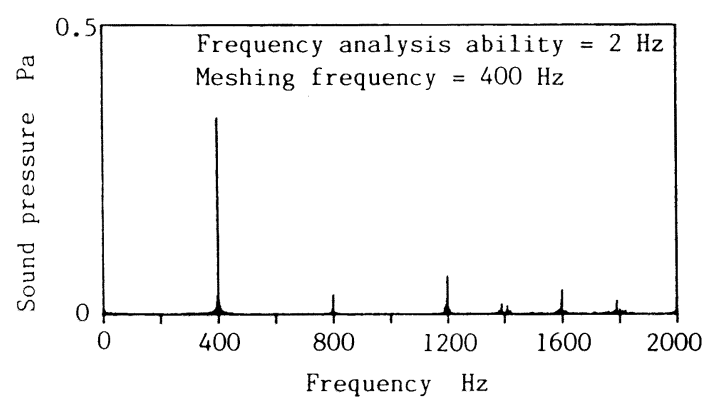

Fig. 9 Spectrum of gear noise (after averaging)

ずかずれたことにより， $\omega_{m}$ がわずかにずれ，その結 果，かみあい周波数の高調波まわりの高次の側帯波ほ ど周波数のずれも大きくなり理論どおりの相殺効果が 得られなかったものと思われる。

\section{4. 結言}

歯車の振動および騒音波形は平均成分と変動成分 (側带波)から成っている。一般に, 歯車の振動や騒音
の間の関係を検討する場合は，平均成分から比較を開 始するのが分かりやすい。ここでは，これらの 2 成分 の中から平均成分を抽出する方法の一つとして移動平 均法を扱った。具体的な処理法としては, 歯車 2 回転 分 (歯数比が $a$ 対 $b$ の場合は小歯車の $2 b$ 回転分) の騒 音や振動波形を準備し, この波形から始点を 1 歯分, 2 歯分, $\cdots$ そして, $Z$ 歯分 ( $b Z$ 歯分) ずらした 1 回転 分 ( $b$ 回転分) の波を切り出し, これらを加え合わせた 後 $1 / Z$ 倍 $(1 /(b Z)$ 倍)すればよい.この方法が平均成 分の抽出法として非常に優れていることを理論および 実測波形の処理例によって示した。また，この移動平 均法は加算平均と同様に SN 比も改善するものであ る.

\section{参 考 文 献}

1）西田知照, 丸木勇治：歯車の偏心誤差と騒音スペクトル, 精密機械, 47, 4（1981）471.

2) 西田知照, 丸木甬治：歯車の偏心誤差と騒音スペクトル (第 2 報) 一一高次の変調波による $\mathrm{FM} ・ \mathrm{AM}$, 精密機械, 51，3 (1985) 547.

\section{情||IIIIII, , , IIIIIII圊}

\section{新素材の潜在市場，21 世紀には 114 兆円}

工業開発研究所 (東京都中央区新川 2-1-7, 理事長・小 林宏治氏, 電話 03-552-4401) では, このほど新材料・新 素子の開発に関する国際戦略をまとめた。

それによると,ファインセラミックス，アモルファス 合金や複合素材など新素材の西暦 2000 年の潜在市場規 模は自由世界全体で約 114 兆円と 83 年実績の 16 倍に払 大されることが予想される。このらち日本の市場規模は 16 兆円で，14\%を占めることになろう.

同調査研究は総合研究開発機構（理事長・下河辺淳氏） の助成研究としてまとめたもので, 先進諸国の新素材開

\section{0 年の新秦材の市場規模}

\begin{tabular}{|c|c|c|}
\hline 新素材内訳 年(西暦) & $\begin{array}{c}1983 \text { 年 } \\
\text { 自由世界(内日本) }\end{array}$ & $\begin{array}{c}2000 \text { 年 } \\
\text { 自由世界(内百 }\end{array}$ \\
\hline $\begin{array}{l}\text { ファインセラミックス } \\
\text { (除光ファイ、等) }\end{array}$ & $3532(678)$ & $28722(5492)$ \\
\hline 光ファイ：等光学材料 & $301(17)$ & $11828(\quad 634)$ \\
\hline 高性能高分子·素材 & $2441(470)$ & $17568(3359)$ \\
\hline 複合材料 & $203(39)$ & $10993(2102)$ \\
\hline 新金属素材 (除太陽電㳐) & $-(-)$ & $11245(2150)$ \\
\hline 太陽電池用素材 & $445(34)$ & $33818(2250)$ \\
\hline 計 & $6922(1238)$ & $114174(15987)$ \\
\hline
\end{tabular}

発状況や潜在需要の推計としてファインセラミックス, 高性能高分子素材, 複合素材, 新金属素材を対象にして 予測したものである.

その推計結果によると, 日本の市場規模はファインセ ラミックスが IC 基板, コンデンサ, 圧着素子など電磁気 的用途を中心に 5 兆 4900 億円に抎大, 高分子素材では エンジニアリングプラスチックが伸びて 3 兆 3500 億円 になる、また新金属類は現在試作中のものが多く，1990 年ごろから実用化, 2000 年に向けて急速に払大すると見 ている. 中でも太陽電池用のシリコン, アモルファス合 金, 超電導合金の潜在需要が高い.

以上を合計した新素材の市場規模は 15 兆 9870 億円で 83 年の 13 倍に達する.

日本の推計結果をベースにした自由世界の市場予 測では, 光ファイバが北米を中心に 11 兆 8200 億 円, 太陽電池用素材は発電適性比の高い東アジア, 北米で潜在需要が高く, その他の一般素材は西欧, 北米, 東アジアの先進工業地域のシェアが王倒的で ある.この結果, 自由世界の市場規模は全体で 114 兆 1700 億円に上るものと予測している.

（服部 敏夫） 